\title{
Antibacterial Activities of the Aqueous and Ethanolic Extracts of the Male and Female Carica papaya Leaves on Some Pathogenic Bacteria
}

\author{
Awah, N.S. ${ }^{1}$, Agu, K.C. ${ }^{1, *}$, IIkedinma, J.C. ${ }^{1}$, Uzoechi, A.N. ${ }^{1}$, Eneite, H.C. ${ }^{1}$, Victor-Aduloju A.T. ${ }^{2}$, \\ Umeoduagu, N.D. ${ }^{3}$, Onwuatuegwu, J.T.C. ${ }^{3}$, Ilikannu S.O. ${ }^{4}$ \\ ${ }^{1}$ Department of Applied Microbiology and Brewing, Nnamdi Azikiwe University, Nigeria \\ ${ }^{2}$ Department of Food Science and Technology, Nnamdi Azikiwe University, Nigeria \\ ${ }^{3}$ Department of Microbiology, Tansian University, Nigeria \\ ${ }^{4}$ Department of Public Health, Federal Medical Centre, Asaba, Nigeria
}

Copyright $\mathrm{C} 2017$ by authors, all rights reserved. Authors agree that this article remains permanently open access under the terms of the Creative Commons Attribution License 4.0 International License

\begin{abstract}
The antibacterial activity of water and ethanol extracts of male and female Carica papaya leaves was carried out on pathogenic isolates. The leaf extracts were prepared by suspending the finely blended leaves separately in distilled water and ethanol. The mixtures were then agitated, decanted, filtered and finally, evaporated to dryness. The antibacterial activity was carried out using the disc diffusion method. The test organisms were Gram negative and Gram positive pathogenic bacteria organisms viz; Escherichia coli, Staphylococcus aureus, Proteus vulgaris, Klebsiella pneumoniae, Bacillus cereus, Salmonella typhi and Pseudomonas aeruginosa. The water extracts yielded no significant antibacterial activity against the test isolates. The ethanol extracts of both male and female papaya leaves demonstrated higher activities against all the Gram negative bacteria than Gram positive bacteria tested. The highest activities (18mm zone of inhibition) were demonstrated against Pseudomonas aeruginosa for the female leaf extract and (17mm zone of inhibition) for the male leaf extract. The Minimum Inhibitory Concentration ranged between $6.25-50 \mu \mathrm{g} / \mathrm{ml}$ and Minimum Bacteriocidal Concentration ranged between $25 \mu \mathrm{g} / \mathrm{ml}-50 \mu \mathrm{g} / \mathrm{ml}$ for both male and female ethanol extracts. Demonstration of antimicrobial activity against the test isolates is an indication that there is possibility of sourcing alternative antibiotic substances in this plant for the development of newer antibacterial agents.
\end{abstract}

Keywords Extract, Antimicrobial, Bacteriocidal, Ethanol

\section{Introduction}

The quest for modern sources of antibiotics is a universal task which is of major concern in research institutions, pharmaceutical companies, and academia, since many infectious agents are becoming resistant to synthetic drugs (Latha and Kannabiran, 2006) ${ }^{[1]}$. The development of resistant strains of pathogenic microorganism continues to create major health concerns about the efficiency of quite a lot of drugs, most significantly antibiotics in present use (Timothy and Idu, 2011) ${ }^{[2]}$. (Sofowora, 1982 and Balandrin et al., 1985) described medicinal plants as a plant in which one or more organs comprise substances that can be used to achieve medicinal goals or which its precursors for the production of drugs are useful for disease therapy ${ }^{[3]}$. Since medicinal plants do not nearly prevent people from feeling pain but allow them to come out unharmed, they merit exploration.

The papaya, CaricapapayaLinn, is a member of the family Caricaceae joined with the Passifloraceae and it is a distinctive source of possibly useful compounds with diverse constitutions and properties (Krishna et al., 2008) ${ }^{[4]}$. Papaya exists in three sexual forms: male, female and hermaphrodite. Papaya flowers are born on inflorescences which emerge in the axils of the leaves. Female flowers are held close against the stem as single flowers or in the group of 2 to 3 (Chay-Prove et al., 2000) ${ }^{[5]}$. Male flowers are smaller and more abundant and are born on 60 to $90 \mathrm{~cm}$ long pendulous inflorescences (Nakasone and Paull, 1998) ${ }^{[6]}$. Bisexual flowers are intermediate between the two unisexual forms (Nakasone and Paull, 1998, Parle and Gurditta, 2011) ${ }^{[7]}$.Papaya (CaricapapayaLinn) is usually known for its food and nutritional values all over the world. The medicinal attributes of papaya fruit and other parts of the plant are also well known in customary system of medicine. Each part of papaya tree has its own economic worth when grown on a business scale (Krishna et al., 2008) ${ }^{[4]}$. Even though the active components are usually obtained from all 
parts of the plant, the concentration of these components vary from structure to structure. However, parts known to have the highest concentration are ideal for therapeutic purposes and it can either be the leaves, stem, barks, roots, bulks, corms, rhizomes, woods, flowers, fruits, and the seeds $\left(\right.$ Kafaru, 1994) ${ }^{[8]}$. C. papaya is known by a collection of names, viz., pawpaw, papaya, papayer, pepol, tinti, chich put, fan kua, wan shoukuo, Kavunagaci, kepaya etc.

The plant parts are found to have some properties like analgesic, amebicide, antibacterial, cardiotonic, cholagogue, digestive, emenagogue, febrifuge, hypotensive, laxative, pectoral, stomachic, and vermifuge properties (Afolayan, $2003)^{[9]}$. Chymenopapain and papain are the two principal bioactive compounds found in C. papaya. Papaya leaves are prepared as tea for the treatment of malaria. The leaves of the papaya plants contain chemical compounds of karpain, substance which kills microorganisms that frequently interrupt the digestive function. Papaya leaf extracts have phenolic compounds, such as protocatechuic acid, p-coumaric acid, 5, 7-dimethoxycoumarin, caffeic acid, kaempferol, quercetin, and chlorogenic acid (Romasi et al., 2011) $)^{[10]}$.

The medical society uses the leaves poultice for nervous pains and elephantoid growths. The leaf is smoked for asthma respite in various remote places. Japanese believe that the consumption of papaya prevent rheumatism. The young leaves and to reduced degree other parts contain carpain, an active bitter alkaloid which has a depressing action on heart. The efficiency of treatment with C. papaya is reliant on the quantity of the various compounds in the preparations. In Nigeria, the leaves are used for smooth upper respiratory tract diseases and tumour (uterus). In Ivory Coast, it is used for treating madness. In Trinidad, it is used for treating scorpion bites and hypertension. In Cote d'Ivoire, it is used for toothache and tuberculosis. In Honduras and Turkey, it is used for liver diseases, constipation and laxatives. In Philippines, India, Malagasy and Malaya, it is used for treating arthritis and rheumatism. In Honduras, Japan, Panama and West Africa, it is used for the treatment of diarrhea and dysentery.

\section{Materials and Methods}

\subsection{Collection and Maintenance of Test Organisms}

Pathogenic isolates of clinical origin were used as test organisms. These isolates include Escherichia coli, Pseudomonas aeruginosa, Klebsiella pneumoniae, Staphylococcus aureus, Bacillus cereus, Proteus vulgaris and Salmonella typhi. They were obtained from the Medical laboratory in St Luke's Hospital, Asaba, Delta State. The organisms were collected on sterile agar slants and incubated at $37^{\circ} \mathrm{C}$ for 48 hours. They were then preserved as stock cultures in the refrigerator set at $4^{\circ} \mathrm{C}$. Biochemical analysis was carried out on each of the test organisms for confirmatory purposes.

\subsection{Confirmatory Tests for Isolates}

The organisms were identified by their colony morphology using Eosin methylene blue for Escherichia coli, Mannitol salt agar for Staphylococcus aureus, MacConkey agar for Klebsiella pneumonia and Proteus vulgaris, Blood agar for Pseudomonas aeruginosa, Salmonella typhi and Bacillus cereus and also, their biochemical reaction, such as Gram reaction, catalase test, oxidase test, Voges-Proskeuer test, methyl-red test, citrate test, sugar fermentation test and motility test.

\subsection{Collection of Plant Materials}

The plant Carica papaya was used for this project work and they were collected from Orchids garden, Asaba and identified as male and female Carica papaya leaves by Mrs. Aziagba.B.O, a botanist from Nnamdi Azikiwe University, Awka. These were then collected in a sterile polythene bag, rinsed, sundried and blended into a powdery form before use.

\subsection{Preparation of Plant Extract}

The water and ethanol extracts was prepared by suspending 100 grams of the finely blended fresh and dried male and female pawpaw leaves separately in $200 \mathrm{ml}$ of distilled water and ethanol. These were then agitated in a rotary shaker for 4-5 days. The extracts was then decanted and filtered through a What man filter paper. The filtered extract was sterilized using a membrane filter and evaporated to dryness over a steam bath at $45^{\circ} \mathrm{C}$. The dried extracts recovered were placed in sterilized screw-capped bottles and stored at refrigeration temperature.

\subsection{Reconstitution of Extracts}

Four grams of the extract was weighed and dissolved in $40 \mathrm{ml}$ of Dimethyl sulfoxide (DMSO) to make a stock concentration of $100 \mathrm{mg} / \mathrm{ml}$ from which the different concentrations used were calculated.

\subsection{Preparation of Antibiotic Discs and Primary Screening of Extracts for Antibacterial Activities}

The disc diffusion technique was employed to ascertain the antibacterial activity of the extracts. Sterile what man No. 1 paper was perforated into $5 \mathrm{~mm}$ diameter disc sizes. The discs were put in a glass Petri plate and oven-sterilize at $180^{\circ} \mathrm{C}$ for 2 hours. Different concentration of the water and ethanol extracts were prepared with diluent (DMSO) at the concentration of $25,50,75$ and $100 \mathrm{mg} / \mathrm{ml}$ in sterile test tubes. Twenty (20) ml of molten Mueller-Hinton (MH) agar were poured into sterile Petri dishes $(90 \mathrm{~mm})$ and allowed to set. Standardized concentrations (McFarland 0.5) of overnight 
cultures of test isolates were swabbed aseptically on the agar plates. The sterile discs were impregnated with the different concentration of the extracts and were gently placed on the appropriately labelled plates. Standard antibiotic discs containing Ciproflox $(10 \mu \mathrm{g})$ was also placed in the inoculated medium to serve as control. These were incubated immediately for $24 \mathrm{~h}$ at $37^{\circ} \mathrm{C}$. After incubation, the clear zones around the discs were measured in $\mathrm{mm}$ scale. This was taken as the zone of inhibition of the test bacteria.

\subsection{Determination of Minimum inhibitory Concentration and Minimum Bactericidal Concentration}

The MIC of the extracts was determined by applying the broth dilution technique (Adebayo et al., 1989) ${ }^{[11]}$. The MIC helps to measure more exactly the concentration of an antibiotic required to inhibit growth of a standardized inoculums under definite conditions (Geo et al., $2001)^{[12]}$.Two-fold serial dilutions were prepared with the extract in nutrient broth. These were then inoculated with small inoculums of $24 \mathrm{hrbroth}$ culture of the test organisms. The culture was then incubated at $37^{\circ} \mathrm{C}$ for 48 hours. The smallest concentration at which growth was inhibited was taken as the MIC. The MBC value was determined after ascertaining the $\mathrm{MIC}$ and the broth dilution technique was employed. The MBC is defined as the lowest concentration of the antibacterial agent that kills at least $99.9 \%$ of the test organism (Geo et al., 2001) ${ }^{[12]}$. To determine this value, about $0.5 \mathrm{ml}$ of the sample was removed from the test tubes used in the determination of MIC in which no desirable growth was observed and spread over the surface of the sterile nutrient agar plates. The lowest concentration of the extract that inhibited the growth of less than $0.1 \%$ of the test organism on the plate was taken to be the $\mathrm{MBC}$ value for the extract.

\section{Results}

The antibacterial activity of water and ethanol extracts of male and female Carica papaya against pathogenic Isolates was carried out. The results of the zone of inhibition in $\mathrm{mm}$ of the different concentrations of ethanol extract of both male and female papaya leaves against the pathogenic isolates are presented in Table 1. The result indicates that the zone of inhibition for the ethanol extract increases with increase in concentration for all test isolates. The result also indicates that Pseudomonas aeruginosa had the highest zones of inhibition among the test isolates for both male and female Carica papaya leaf extracts. There were no zones of inhibition for Bacillus cereus at lower concentrations of both male and female papaya leaf extracts.

The results of the zone of inhibition in $\mathrm{mm}$ of the different concentrations of water extract of both male and female papaya leaves against the pathogenic isolates are presented in Table 2. The result indicates that the water extracts of both male and female papaya leaves yielded no significant antibacterial activity against the test isolates.

The Minimum Inhibitory Concentration and Minimum Bactericidal Concentration of the ethanol extracts for both male and female papaya leaves against the test isolates were also carried out. The results of the MIC and MBC in $\mu \mathrm{g} / \mathrm{ml}$ are presented in Table 3. The result depicts that only Bacillus cereus and Proteus vulgaris had MIC $(\mu \mathrm{g} / \mathrm{ml})$ values of 50 and 25 for the female leaf extracts whereas, the male had no MIC for the organisms. Bacillus cereus had the highest MIC value followed by Klebsiella Pneumoniae and Proteus vulgaris with the same MIC value of $25 \mu \mathrm{g} / \mathrm{ml}$. Pseudomonas aeruginosa, Salmonella typi and Staphylococcus aureus had the lowest MIC value for both male and female leaf extracts. The result also indicates that E.coli among the test isolates produced the highest MBC value for male and female leaf extracts. This was followed by Pseudomonas aeruginosa, Salmonella typi and Staphylococcus aureus having MBC value of $24 \mu \mathrm{g} / \mathrm{ml}$ each whereas Klebsiella Pneumoniae, Bacillus cereus and Proteus vulgaris had no MBC value for both male and female leaf extracts.

Table 1. Zone of inhibition in $(\mathrm{mm})$ of the different concentrations of ethanol extract of the Female Carica papaya leaves and control on the test isolates

\begin{tabular}{|c|c|c|c|c|c|}
\hline $\begin{array}{c}\text { Concentrations(mg/ml) } \\
\text { Ciproflox(mcg) }\end{array}$ & $\mathbf{2 5}$ & $\mathbf{5 0}$ & $\mathbf{7 5}$ & $\mathbf{1 0 0}$ & Control \\
\hline $\begin{array}{c}\text { Pseudomonas } \\
\text { aeruginosa }\end{array}$ & $4(-)$ & $9(7)$ & $14(14)$ & $18(17)$ & 25 \\
\hline Klebsiella pneumonia & $-(-)$ & $-(-)$ & $4(3)$ & $9(7)$ & 23 \\
\hline Salmonella typhi & $-(-)$ & $5(3)$ & $10(9)$ & $17(16)$ & 22 \\
\hline Escherichia coli & $-(-)$ & $3(5)$ & $9(9)$ & $16(14)$ & 17 \\
\hline Staphylococcus aureus & $3(2)$ & $7(6)$ & $12(10)$ & $16(15)$ & 25 \\
\hline Bacillus cereus & $-(-)$ & $-(-)$ & $-(-)$ & $7(5)$ & 13 \\
\hline Proteus vulgaris & $-(-)$ & $2(-)$ & $7(4)$ & $10(8)$ & 18 \\
\hline
\end{tabular}

Note: Figures in Parenthesis indicates the result for the male Carica papaya leaf extract.

Table 2. Zone of inhibition in ( $\mathrm{mm}$ ) of the different concentrations of water extract of the Female Carica papaya leaves and control on the test isolates

\begin{tabular}{|c|c|c|c|c|c|}
\hline $\begin{array}{c}\text { Concentrations(mg/ml) } \\
\text { Ciproflox(mcg) }\end{array}$ & $\mathbf{2 5}$ & $\mathbf{5 0}$ & $\mathbf{7 5}$ & $\mathbf{1 0 0}$ & Control \\
\hline $\begin{array}{c}\text { Pseudomonas } \\
\text { aeruginosa }\end{array}$ & $0(0)$ & $0(0)$ & $0(0)$ & $0(0)$ & 25 \\
\hline Klebsiella pneumoniae & $0(0)$ & $0(0)$ & $0(0)$ & $0(0)$ & 23 \\
\hline Salmonella typhi & $0(0)$ & $0(0)$ & $0(0)$ & $0(0)$ & 22 \\
\hline Escherichia coli & $0(0)$ & $0(0)$ & $0(0)$ & $0(0)$ & 17 \\
\hline Staphylococcus aureus & $0(0)$ & $0(0)$ & $0(0)$ & $0(0)$ & 25 \\
\hline Bacillus cereus & $0(0)$ & $0(0)$ & $0(0)$ & $0(0)$ & 13 \\
\hline Proteus vulgaris & $0(0)$ & $0(0)$ & $0(0)$ & $0(0)$ & 18 \\
\hline
\end{tabular}

Note: Figures in Parenthesis indicates the result for the male Carica papaya leaf extract. 
Table 3. Minimum Inhibitory Concentration (MIC) and Minimum Bactericidal Concentration (MBC) of the female papaya leaf extracts against test isolates

\begin{tabular}{|c|c|c|}
\hline $\begin{array}{c}\text { Concentrations(mg/ml) } \\
\text { Ciproflox(mcg) }\end{array}$ & $\operatorname{MIC}(\mu \mathrm{g} / \mathrm{ml})$ & $\operatorname{MBC}(\mu \mathrm{g} / \mathrm{ml})$ \\
\hline Pseudomonas aeruginosa & $6.25(6.25)$ & $25(25)$ \\
\hline Klebsiella pneumoniae & $25(25)$ & $-(-)$ \\
\hline Salmonella typhi & $6.25(6.25)$ & $25(25)$ \\
\hline Escherichia coli & $12.5(25)$ & $50(-)$ \\
\hline Staphylococcus aureus & $6.25(6.25)$ & $25(25)$ \\
\hline Bacillus cereus & $50(-)$ & $-(-)$ \\
\hline Proteus vulgaris & $25(-)$ & $-(-)$ \\
\hline
\end{tabular}

Note: Figures in Parenthesis indicates the result for the male Carica papaya leaf extract.

\section{Discussion}

The water extract of both male and female papaya leaves yielded no significant antibacterial activity against the test isolates used while the ethanol extract of both male and female leaves demonstrated high antibacterial activity against both Gram negative and Gram positive test isolates used. Although both the male and female extracts demonstrated high antibacterial activities against the test isolates, the female extract was slightly more effective than the male extract with the highest activity $(18 \mathrm{~mm}$ zone of inhibition) demonstrated against Pseudomonas aeruginosa when compared with the male leaf extract which demonstrated (17 $\mathrm{mm}$ zone of inhibition) against Pseudomonas aeruginosa. The inhibition zones of the extracts were compared to that of the control and the activity of the extracts was as good as that of the antibiotic.

The presence of bioactive substances have been said to convey resistance to plants against bacteria, fungi and pests and hence explicates the demonstration of antibacterial activity by the plant extracts (Srinivasan et al., 2001) ${ }^{[13]}$. The results of this study showed that the ethanol extracts were more effective than water extracts which demonstrated no significant antibacterial activity. This may be as a result of the enhanced solubility of the active components in organic solvents (De Boer et al., 2005) ${ }^{[14]}$. Aqueous, n-hexane and ethanol extract of Carica papaya leaves was investigated by Chandra et al., (2011) for antibacterial activity of Staphylococcus aureus, Bacillus subtilis, Escherichia coli, and Pseudomonas aeruginosa and it was noted that amongst the three extracts n-hexane and ethanol had highest inhibition of Staphylococcus aureus while aqueous had a lower zone of inhibition of Bacillus subtilis, Escherichia coli, and Pseudomonas aeruginosa ${ }^{[15]}$.

Amongst the Gram-positive and Gram-negative bacteria tested, the Gram-negative bacteria were more susceptible to the ethanol extract of male and female $C$. papaya leaves, especially $P$. aeruginosa. Mangalanayaki and Nirosha, (2013) studied the antibacterial activity of the leaves of the Carica papaya using solvents ethanol and ethyl acetate against Staphylococcus aureus, Streptococcus pneumoniae, Bacillus cereus, Salmonella typhi, Escherichia coli and Pseudomonas aeruginosa by well diffusion method ${ }^{[16]}$. The extract displayed higher activities against the Gram negative bacteria than Gram positive bacteria used and the highest activity (16 $\mathrm{mm}$ zone of inhibition) was demonstrated against Salmonella typhi. This result, however is contradictory to an earlier report denoting that plant extracts are more effective against Gram-positive bacteria than Gram-negative bacteria. (Jigna and Sumitra, 2006) ${ }^{[17]}$.

The demonstration of activity against the test bacteria presents scientific grounds for the traditional use of these plants in the treatment of several illnesses. The fact that the extracts were active against both Gram-negative and Gram-positive bacteria tested may insinuate a broad spectrum of activity. This finding is very important because of the likelihood of producing therapeutic substances that will be active against many drug-resistant organisms.

The low MIC value detected for S. aureus is a great sign of high efficacy against the bacterium. (Jigna and Sumitra, $2006)^{[15]}$. This result is significant because of the increase in boil, breast abscess and surgical wound infection etc. caused by $S$. aureus and also they are more becoming resistant to first-line antibiotics for its treatment especially in developing countries, including Nigeria. High MIC may be a sign of low efficiency that the organisms may probably develop resistance to the bioactive compounds.

The ineffectiveness of the water extract and the decreasing concentration of the ethanol extract could be because of the following as specified by Bernice, (1997) ${ }^{[16]}$;

- Site of harvest should never be part- treated with insecticides.

- Time of collection should be when the leaf or plant grows most and collection should also be during the day.

- Drying method: Sometimes, active agents of leaves are destroyed by direct contact with sunlight or by drying in the hot air oven especially if the active agent is volatile.

- Once dried, herbs should be dated, labelled and stored in area not exposed to light, moisture or heat.

- It could also be due to the extractant employed and the means utilized to get the active component (Unaeze and Abrikwa, 1989 ${ }^{[17]}$.

Since this research work has disclosed the impotency of water extracts of male and female leaf extract of papaya, more researches should be done making use of the leaves dried at room temperature instead of sun or oven drying to observe if this had influenced the ineffectiveness of the extracts $^{[20-22]}$. The results of the research work also encourages the local use of the plant and proposes that the plant extracts has compounds with antibacterial properties which can be utilized as antibacterial agents in original drugs for the treatment of gastroenteritis, uretritis, otitis media, and wound infections. Additional pharmacological assessments, toxicological researches and isolation of the therapeutic 
antibacterial from this plant are the upcoming challenges ${ }^{[23-24]}$.

\section{Conclusions}

The result of this research revealed that ethanol extract of male and female Carica papaya leaves both has inhibitory effect on some pathogenic bacteria organisms while the water extract has no significant antibacterial activity. It also showed that the extract generally has a higher antibacterial activity against Gram negative test isolates than Gram positive test isolate, although it effectively inhibited the growth Staphylococcus aureus.

The extracts were active against both Gram-negative and Gram-positive bacteria tested. This indicates a broad spectrum of activity. This study is very important because of the possibility of developing therapeutic substances that will be active against several drug-resistant organisms.

\section{REFERENCES}

[1] Latha, S.P. and Kannabiran, K. (2006). Antimicrobial activity and phytochemicals of Solanumtrinobatumlinn. African Journal of Biotechnology. 5(23): 2402-2404.

[2] Timothy, O. and Idu, M. (2011). Preliminary phytochemistry and in vitro antimicrobial properties of aqueous and methanol extracts of Icacina trichantha. Olive Leaf. 1(3): 184-188.

[3] Sofowora, A. (1982). Medical Plants and Traditional Medicine in west Africa, Spectrum Books Ltd., Ibadan, in association with john Wiley and Sons, London. Pp. 204-208.

[4] Krishna, K.L., Paridhavi, M., and Patel, J.A. (2008). Review on nutritional, medicinal and pharmacological properties of papaya (Carica papaya linn.) natural product radiance. Indian Journal of Natural Products and resources. 7(4): 364-373.

[5] Chay-Prove, Rose P, O'Hare P, Maclead N, Kernot I, Evans D, Grice K, Vawdrey L, Richards N. (2000). Vitaceae and Cyperusrotundus L. (Cyperaceae). African Journal of biomedical Research. 9(2): 89-93.

[6] Nakasone \& Paull. (1998). Papaya. Agricultural Biotechnology. 2: 17-19.

[7] Parle M, Gurditta (2011). Basketful benefits of papaya. International Research Journal of Pharmacy. 2(7): 6-12.

[8] Kafaru, E. (1994). Immense Help from Natives Workshop, $1^{\text {st }}$ Ed., Elizabeth Kafaru, Lagos, Nigeria. Pp. 11-14.

[9] Afolayan, A.J. (2003). Extracts from the shoots of Arctotis artotoides inhibit the growth of bacteria and fungi. Pharmaceutical Biology. 41: 22-25.

[10] Romasi E F, Karina J K, Parhusip A J N. (2011). Antibacterial Activity of Papaya Leaf Extracts against pathogenic bacteria. Makara Journal of Technology Series. 15(2): 27-30.
[11] Adebayo, A.C., Oloke, J.K., and Aladesanmi, A.J. (1989). Antimicrobial activities of the leaf of Eugenia Uniflora. Phytotherapy research. 3(6): 258-259.

[12] Geo, F., Brooks, J.S.B. and Stephen, A.M. (2001). Jaetz, Melnick and Adeberg's Medical Microbiology, $22^{\text {nd }}$ edition's. 607.

[13] Srinivasan, D., Perumalsamy, L., Nathan, P. Sures, T. (2001). Antimicrobial activity of certain Indian medicinal plants used in folkloric medicine. Journal of Ethnopharmacy. 94: 217-222.

[14] De Boer, H. J., Kool, A., Broberg, A., Mziray, W. R., Hedberg, I. and Levenfors, J. J. (2005). Antifungal and Antibacterial activity of some herbal remedies from Tanzania. Journal of Etnopharmacolgy. 96: 461469.

[15] Chandraet, G., Ghosh, A., Chatterjee, SK., Bhattacharjee, I. (2011). Antibacterial activities of some plant extracts used in Indian traditional folk medicine. Asian Pacific Journal of Tropical Biomedicine.165-169.

[16] Mangalanayaki, R. and Nirosha, N. (2013). Antibacterial Activity of Leaves and Stem Extract of Carica papaya $L$. International Journal of Advances in Pharmacy, Biology and Chemistry. 2(3): 473-476.

[17] Jigna, P. and Sumitra, C. (2006). In-vitro antimicrobial activities of extracts of Launaeaprocumbns Roxb. (Labiateae), Vitisvinifera (Vitaceae) and Cyperus rotundus L. (Cyperaceae). African Journal of biomedical Research. 9(2): 89-93.

[18] Bernice, T. (1997). Medicinal Herbs: Current uses of some not so new medicines. PMAP Conference.

[19] Unaeze, M.C. and Abarikwa, P. O. (1986). Antimicrobial activity of certain medicinal plant used in traditional medicine in Nigeria: A preliminary study. Journal of Microbiology. 6(2): 32-40.

[20] Adindu, C.S., Odili, L.C., Nwagu, E.E., Agu, K.C., Awah, N.S., Okeke, B.C. and Orjionwe, R.N. (2016). Phytochemical and Antimicrobial Screening of Cola gigantea Leaves, Stem and Bark. Universal Journal of Microbiology Research, 4 (2): 49-54

[21] Agu, K.C., Igweoha, C.A. and Umeh, C.N. (2013). Antimicrobial Activity of the Ethanolic and Petroleum Ether Extracts of Tangerine Seed on Selected Bacteria. International Journal of Agriculture and Bioscience, 2 (1); 22-24.

[22] Frank, C.O. and Kingsley C.A. (2014). Roles of Fungal Rots in Post-Harvest Storage Losses in some Nigerian varieties of Dioscorea species. British Microbiology Research Journal. 4 (3): 343-350

[23] Okafor, A.C., Igwesi, S.N., David, E.E., Okolo, V.K. and Agu, K. (2016). Presence of Bacteria with Pathogenic Potential Among Already-Used Toothbrushes From University Students. American Journal of Life Science Researches, 4 (3):16-20

[24] R.N. Okigbo, C.E. Enweremadu, K.C. Agu, R. CIrondi, B.C., Okeke, S.N. Awah, C.G. Anaukwu, I.O. Okafor, C.U., Ezenwa, A.C. Iloanusi, (2015). Control of white yam (Dioscorea rotundata) rot pathogen using peel extract of water yam (Dioscorea alata). Advances in Applied Science Research, 6 (10): 7-13. 